\title{
The Import and Export Market in Brazil in the 20th and 21st Centuries: Economic, Historical and legal Analysis ${ }^{1}$
}

\author{
By Cláudia Ribeiro Pereira Nunes* \\ Kaiser Motta Lucio de Morais ${ }^{\dagger}$
}

This study aims to provide a panoramic view of the Brazilian import and export market, also nicknamed the Contemporary Market, in order to better understand the application of the principle of free enterprise and the importance of this market in the development of Brazil in the second half of the twentieth century and early 21st century. To attain the proposed objective, the authors use a literature review of renowned authors of law and economics, in addition to presenting several tables on market growth to facilitate understanding of its development.

Keywords: Import market, export market, economic history, positive and negative points.

\section{Introduction}

When Brazilian lawyers talk about free enterprise as the foundation of the Republic and the founding principle of economic order, as a development tool of the import and export market, it is necessary to understand the historical importance of this segment of the Brazilian economy which justifies the research work at hand.

The aim of this paper is to develop historical paradigms to prove that today's import and export market is essential to the economic growth of the country, without applying economic models. To this end, we use as a mainstay, the classification of economists FIPE-USP - Foundation Institute of Economic Research at the University of São Paulo, and the teachings of Marco Antonio Sandoval de Vasconcelos, Amaury Patrick Gremaud and Rudinei Toneto

\footnotetext{
${ }^{1}$ C.R.P. Nunes is grateful to Gabriela Quinhones de Souza, Dean and Professor of Law of this Institution, who furnished very useful information and provided excellent research assistance for the draft. The author is also thankful to the Research Group at the University Center of Barra Mansa - UBM, who encouraged the systematic study. K.M.L. de Morais is grateful to Volia Bonfim Cassar, Law Dean, and Edson Medeiros Branco Luiz, Academic Coordinator of Law of this Institution, who furnished very useful information and provided excellent research assistance for the draft, and is also thankful to the Research Group at the University Grande Rio - UNIGRANRIO, who encouraged the systematic study. Both authors are obliged to give particular thanks to Gary Cohen - UBM English Review - in its form and content and Rafael Gonçalves - Historical Economic junior research student, who were very helpful about economic terminology.
}

*PhD, Professor, University Center of Barra Mansa - UBM, Rio de Janeiro, Brazil.

${ }^{\dagger}$ MSc, Professor, University of Grande Rio - UNIGRANRIO, Rio de Janeiro, Brazil. 
Junior, as described in their book Contemporary Brazilian Economy which divides the Brazilian economy into the five major phases below:

1) The import substitution process;

2) Replacement policy crisis of imports and institutional reforms in PAEG (Government Economic Action Plan);

3) Economic miracle and the 2nd National Development Plan - II NDP;

4) The crisis of the 80s: the external adjustment process, and the 90s: antiinflation policies; and

5) First decade of this century.

A panorama of the "first decade of this century" will then be presented to provide a historical overview of the Brazilian economy, positive or negative, which affects the import and export market of companies in Brazil.

The methodology used in the article is a literature review along with the obtaining of secondary data from official sites to confirm the development of the market studied in each stage of the Brazilian economy.

\section{Globalization of the Import and Export Market}

Globalization is currently an irreversible process of experience of great proportion in the world economy, surpassing trade liberalization in determining the status of any country in the international scenario. Participation in international trade becomes a defining element of national economic growth, since it is no longer possible to conceive of a country with an isolated and closed economy. Globalization has created a worldwide space of economic interdependence demonstrating that the economic growth and development of countries are closely interlinked. (ANKIW, 2001:19)

Competition for trade and the survival of business in a globalised world has become fierce, requiring improvement of means of production, increased training of skilled labour and technological increments, and, in some cases, necessitating sensitive economic government policies for the operation of businesses in the import and export sectors. This is also the reality for Brazilian companies. ${ }^{1}$

Despite the existence of other entities being involved in the import and export sector in Brazil, the exercise of control and supervision of foreign trade is carried out by the Ministry of Finance, pursuant to article 237 CRFB through the Secretariat of the Federal Tax, whose customs inspectors, in seeking to meet national financial interests, end up creating barriers to Brazilian companies in this strategic economic segment which adds to the natural difficulties experienced by companies today.

${ }^{1}$ Pinho, Vasconcelos \& Ttoneto Júnior, 2011: 16-18 


\section{Economic, Historical and Legal Analysis Applied to the Import and Export Market}

\section{The Import Substitution Process}

During the Old Republic of 1889-1930, the Brazilian economy depended primarily on the performance of exports, which, in that period, were restricted to a few agricultural commodities such as planted coffee in the southeast region of the country. This characterised the Brazilian economy during the agroexport era and inserted it in the world economy during the colonial period. Sugar, gold, cotton and rubber were later exports.

It should be noted that Brazil, at the time, despite having the title of one of the largest coffee producers, had no control of prices, and thus depended solely on fluctuations in world growth to achieve economic results. ${ }^{1}$

In 1930, when the global economy experienced one of the biggest crises in its history, it remains clear that the Brazilian economic situation was dependent on exports of a single agricultural product, and was unsustainable ${ }^{2}$. Consequently, this proved to be a rupturing moment in economic development since the weakening of the agro-export model raised the awareness for the need of industrialization as an instrument to overcome external constraints and underdevelopment. It was the beginning of Brazilian industrialization (which had already begun in the late nineteenth century), which in that moment became a primary goal of economic policy ${ }^{3}$.

Due to the external strangulation created by the international crisis of the New York Stock Exchange, it was necessary to internally produce what had been imported, to defend economic activity. Industrialization was driven by the process of import substitution, called closed industrialization, inward-looking, i.e., aimed at the domestic market ${ }^{4}$.

Hence, the process of import substitution known as the target plan (19561960) adopted by the government of Juscelino Kubitschek, which lasted over thirty years through periods of peak and high growth, was born. During this era, the Brazilian economy suffered mishaps and difficulties, and was substantially modified to suit the characteristics of industrialization and urbanization.

\section{The Crisis of the 60s and the PAEG (Government Economic Action Plan)}

The early '60s were marked by the first great economic crisis in Brazil during its industrial phase. During this period, there was a sharp drop in investment and the growth rate of income plummeted. In order to move forward with economic development it became imperative to broaden the capital goods sector, to expand the intermediate goods segment and to improve urban infrastructure.

However, to awaken these sectors, public funding was necessary, which

\footnotetext{
${ }^{1}$ Tavares (1975) 25.

${ }^{2}$ Tavares (1975) 29-30

${ }^{3}$ Fausto, (1997) 105.

${ }^{4}$ Tavares (1975) 60.
} 
was scarce due to the high public deficit coming from expenses incurred by the goals of the Kubitschek administration. The scenario in this period was one of political crisis, falling foreign exchange revenue arising from exports, and the acceleration of inflation ${ }^{1}$.

Aiming to reverse this scenario, the Castelo Branco government launched the PAEG (Government Economic Action Plan), which established specific policy actions to combat inflation, linked to structural reforms that allowed the equation of inflationary problems to overcome obstacles of economic growth ${ }^{2}$. In general, the PAEG objectives were: to stimulate the pace of economic development, to stop the inflationary process, to reduce regional economic and sector inequalities, to increase investment with consequent job creation and to reduce the tendency of external disequilibrium ${ }^{3}$.

As is shown by the data presented in the table below, it is clear that this cycle had lower growth rates and very high inflation rates:

Table 1. GDP Growth Rates and Inflation (1962-1967)

\begin{tabular}{c|c|c|c}
\hline Year & GDP Growth (\%) & $\begin{array}{c}\text { Growth of } \\
\text { Industrial } \\
\text { Production }(\%)\end{array}$ & $\begin{array}{c}\text { Inflation Rate } \\
\text { (IGP- DI) }(\%)\end{array}$ \\
1962 & 6.6 & 8.1 & 45.5 \\
1963 & 0.6 & -0.2 & 83.2 \\
1964 & 3.4 & 5.0 & 84.5 \\
1965 & 2.4 & -4.7 & 31.4 \\
1966 & 6.7 & 11.7 & 34.2 \\
1967 & 4.2 & 2.2 & 21.2 \\
\hline
\end{tabular}

Source: Economic Environment

PAEG reforms were successful in changing the Brazilian economic picture, especially the economic picture in the customs sector which sought to stimulate and diversify Brazilian exports with a series of tax incentives, and by modernizing and streamlining agencies related to international trade such as CACEX and CPA. During this period, with the reduction of inflation and attraction of foreign capital, the stage was set for a resumption of growth in the decade of the 1970s.

The Brazilian Economic Miracle and the 2nd National Development Plan - II NDP

The economic cycle from 1968 to 1973, called "the Brazilian Economic Miracle" was characterised by the highest GDP growth rates in the country's recent history, with relative price stability and average GDP growth greater than $10 \%$ per year. In addition to a strong global economic cycle, institutional

\footnotetext{
${ }^{1}$ Doellinger (1974) 29.

${ }^{2}$ Villela \& Baer (1980) 65

${ }^{3}$ Batista (1987) 40
} 
reforms developed in the previous recession also contributed to the growth recovery which eliminated idle capacity in industry.

In the area of foreign policy, state export taxes were abolished, administrative procedures for exports were simplified, and the creation of tax incentive programs and subsidised credit for exporters was implemented. These measures stimulated an increase of 2.5 times the volume of exports, which enabled the rapid economic growth of this cycle.

However, despite these efforts, the Brazilian economy was still very vulnerable to external economics. With the arrival of the global oil crisis in 1973 - when OPEC quadrupled the price of oil - the expansion cycle ended. In the following years, there was a significant increase in the inflation rate from $15.5 \%$ in 1973 to $34.4 \%$ in $1974^{1}$ which began the trend of economic slowdown.

Werner Baer argues that, at the time, Brazil had two options to address the oil crisis. The first was to substantially reduce growth in order to reduce the country's imports unrelated to oil, while the second was to continue growth policies supporting the GDP. However, such a situation would cause a decline of the reverse exchange and a large increase in external debt. Brazil chose the second alternative, introducing the 2nd National Development Plan - II NDP 2 .

II NDP essentially consisted of an investment program which had as its main goals a new round of import substitution of basic industrial products (steel, aluminium, copper, fertilisers and petrochemicals) and the search for a rapid expansion of economic infrastructure (hydro and nuclear energy, ethanol production, transport and communications).

Given these changes in national development policy and investment, the choice for growth maintained an annual average rate of about $7 \%$ for nearly a decade, and an approximate annual industrial growth of $7.5 \%$; however not like the miracle years.

In contrast, external debt grew rapidly in the period, $\$ 15$ billion from 1974-1977 and \$17 billion from 1978-1979. In order to run II NPD, the state became a passive instrument to maintain economic growth and the functioning of the economy. Due to extremely low levels of international interest rates at the time, the state was able to pay the interest, although risking that any modification in the structure of interest rates could derail payment terms, particularly due to the floating characteristic of lending rates.

The deterioration of state funding capacity, which socialised all costs in the II NPP period (with large increases in spending without creating appropriate financing mechanisms), would soon be in big trouble confronting the Brazilian economy.

The Crisis of the 80s - the External Adjustment Process - and the 90s - Antiinflation Policies

In the late 70 s and early 80 s, the second oil crisis caused great changes in

\footnotetext{
${ }^{1}$ Villela \& Baer (1980) 65.

${ }^{2}$ Baer (1996) 105.
} 
the international arena stimulating the reversal of international financing conditions, and thereby raising interest rates. In this environment, the Brazilian foreign debt curve increased, and the internal public deficit generated inflationary pressures leading to a jump in inflation in 1979 to $77 \%{ }^{1}$.

The cause of this change was a change in US policy, which, because of the second oil crisis, adopted a restrictive strategy aimed at containing the trend of devaluation of the dollar due to the floating exchange rate. In fact, the American credit restriction policy forced an adjustment of the economy.

In this context of higher rates and greater difficulties in obtaining resources, that is, the rolling over of accrued liabilities, many countries such as Brazil found themselves in deep trouble with foreign debt, leading, in some cases, to insolvency, such as in the Mexican moratorium. Brazil entered a deep recessionary process with a drop in per capita income, and only succeeded in accelerating the economy after 1982, motivated by export stimulus ${ }^{2}$.

In view of high inflation rates from 1985 onwards, economic policy had as its main goal the fight against inflation ${ }^{3}$. Since this time, the reduction of inflation rates has been attempted in various ways, with a number of economic plans aimed at a sudden drop in inflation interspersed by periods of orthodox control.

This was a phase in the government of Fernando Henrique Cardoso (FHC), marked by great fluctuation in inflation rates and the complete deterioration of public accounts ${ }^{4}$. Despite the efforts of those plans, it was only in the current plan (1994) that inflation was reduced to levels considered for a developing country as shown in the graphic below:

\footnotetext{
${ }^{1}$ Paulani, L. et al (1987) 87.

${ }^{2}$ Pinho, Vasconcelos \& Toneto Júnior (2011) 91.

${ }^{3}$ Pinho, Vasconcelos \& Toneto Júnior (2011) 94.

${ }^{4}$ Bacha (1995) 19.
} 
Graphic 1. Inflation Tax (\%) - (1986-1997)

Inflação Mensal (\%)

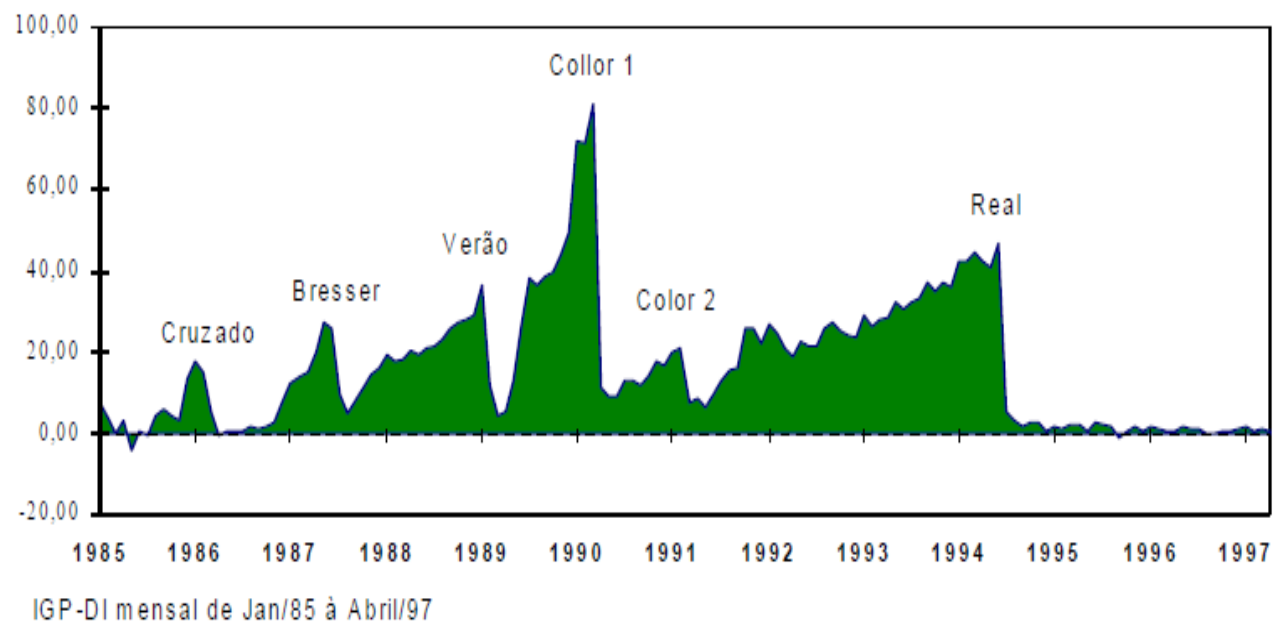

Fonte: Banco Central

Source: Brazilian Central Bank - FUNDAP Economic group

The successful anti-inflation policy of the Real Plan was accomplished based on two main points: first, fiscal adjustment measures, and secondly, the creation of a new indexing system that gradually led to the creation of a new currency through the URV index - Real Value Unit, which was linked to the dollar, one-to-one ${ }^{1}$. These measures brought great impact to the import and export sector which portrays these transformations.

Thus, the fall of import barriers led to a rapid evolution of economic growth and rising incomes, which led to a significant increase in the volume of imports. In the field of exports, volume also increased as a result of that exchange rate policy ${ }^{2}$.

\section{First Decade of this Century}

The government of the Workers Party and its coalition (Lula da Silva and Dilma Rousseff), and Nelson Barbosa, a professor at UFRJ Economics Institute, said that "the main lines of the macroeconomic policy regime of the Cardoso government (inflation targeting systems, primary surpluses and floating exchange rate) were maintained by the Lula government." ${ }^{3}$ However, it was only during the second term of the Lula administration, and the administration of his successor Dilma Rousseff, that greater flexibility in the management of economic policy was achieved ${ }^{4}$.

As a result of this trend, exports, beginning from 2003, began to contribute increasingly to the GDP. The average rate of export contribution to GDP growth between 2003 and 2006 was $1.5 \%$, equivalent to approximately $42.8 \%$

\footnotetext{
${ }^{1}$ Vasconcelos, Gremaud \& Tonedo Júnior (1999) 23.

${ }^{2}$ Vasconcelos, Gremaud \& Tonedo Júnior (1999) 34.

${ }^{3}$ Barbosa \& Souza (2010b) w/p.

${ }^{4}$ Vasconcelos, Gremaud, \&Tonedo Júnior (1999) 59.
} 
of the average GDP growth in the same period ${ }^{1}$. This increase in exports led to an increase in investments in absolute and relative terms, in the economic groups of the commodities industry, urging the expansion of investment between 2003 and 2006. (See table 2 below)

Table 2. Evolution of the Brazilian Foreign Trade 2000-2011

\begin{tabular}{|c|c|c|c|c|c|}
\hline & \multicolumn{2}{|c|}{ BRAZIL EXPORTS (FOB) } & \multicolumn{2}{c|}{ BRAZIL IMPORT (FOB) } & TRADE BALANCE (FOB) \\
\hline Year & US\$ Bi & $(\boldsymbol{\%})$ & US\$ Bi & $\mathbf{( \% )}$ & US\$ Bi \\
\hline 2000 & $\mathbf{5 5 . 1}$ & 14.8 & $\mathbf{5 5 . 9}$ & 13.3 & $\mathbf{- 0 . 7}$ \\
2001 & $\mathbf{5 8 . 3}$ & 5.7 & $\mathbf{5 5 . 6}$ & -0.4 & $\mathbf{2 . 7}$ \\
2002 & $\mathbf{6 0 . 4}$ & 3.7 & $\mathbf{4 7 . 2}$ & -15 & $\mathbf{1 3 . 2}$ \\
2003 & $\mathbf{7 3 . 2}$ & 21.1 & $\mathbf{4 8 . 3}$ & 2.3 & $\mathbf{2 4 . 9}$ \\
2004 & $\mathbf{9 6 , 7}$ & 32.1 & $\mathbf{6 2 . 8}$ & 30 & $\mathbf{3 3 . 8}$ \\
2005 & $\mathbf{1 1 8 . 5}$ & 22.6 & $\mathbf{7 3 . 6}$ & 17.1 & $\mathbf{4 4 . 9}$ \\
2006 & $\mathbf{1 3 7 . 8}$ & 16.3 & $\mathbf{9 1 . 4}$ & 24.1 & $\mathbf{4 6 . 5}$ \\
2007 & $\mathbf{1 6 0 . 6}$ & 16.6 & $\mathbf{1 2 0 . 6}$ & 32 & $\mathbf{4 0}$ \\
2008 & $\mathbf{1 9 7 . 9}$ & 23.2 & $\mathbf{1 7 3}$ & 43.4 & $\mathbf{2 5}$ \\
2009 & $\mathbf{1 5 3}$ & -22.7 & $\mathbf{1 2 7 . 7}$ & -26.2 & $\mathbf{2 5 . 3}$ \\
2010 & $\mathbf{2 0 1 . 9}$ & 32 & $\mathbf{1 8 1 . 8}$ & 42.3 & $\mathbf{2 0 . 1}$ \\
2011 & $\mathbf{2 5 6}$ & 26.8 & $\mathbf{2 2 6 . 2}$ & 24.5 & $\mathbf{2 9 . 8}$ \\
\hline
\end{tabular}

Source: Export and Import Brazilian: SECEX / MDIC and RFB / MF 2011

The table above shows the performance of Brazilian foreign trade during the last decade, highlighting a favourable balance of trade, world economic growth, the increase in international commodities prices and diversification of export markets. The largest national productivity industry favoured the dynamism of Brazilian exports, which had successive records until the global economic crisis of $2008 .^{2}$

Despite the financial crisis of 2008 - which caused significant changes in the international market and hindered expansion of the commercial dynamism of many developed countries, and therefore of developing countries - Brazil, despite the fall in its balance of trade during this period, grew stronger from the crisis and returned to have positive results until 2011. This was the result of a primary surplus policy of the Government of Dilma Rousseff.

\footnotetext{
${ }^{1}$ Barbosa \& Souza (2010a) w/p.

${ }^{2}$ Cintra \& Acioly (2012) 56.
} 
After the financial crisis of 2008, the economic situation showed what are the limits of Brazil's growth model in which is associated income redistribution and consumption of masses with orthodoxy of economic policy, which had remained in the government of Luiz Inacio Lula da Silva and in the first term of the Rousseff government.

Arguably, the result of above alluded combination was the expansion of consumption, with clear boundaries as to its sustainability limited to a certain number of years. It should be noted, moreover that, growth rates, the time was more important than those of today, is the regressive specialization of exports, is the breakdown of domestic and supply chains reducing the multiplier effects of redistributive policies expand demand ${ }^{1}$.

\section{Conclusion}

The economic model established by Article 170 of the CRFB enshrines the principle of free enterprise as the basis for construction of economic order, however, the same Article limits business activities to be entrusted to the mandatory achievement of social goals, since social values are also established as the foundation of Brazilian economic order.

Thus, the legal system established by the Constitution of 1988 established the principle of a social role as a cornerstone of the exercise of economic activities of enterprises.

Therefore, in order to complement the discussion launched by this study, the social function of the company and its applicability in the import and export market.

From 2008 to 2012, due to the crisis that developed in the US and Europe, and increased competition offered by China - eager for new markets in which it could sell its manufactured products - it was clear that in addition to demand policies, policies to increase investments and competitiveness, and innovation in the Brazilian productive sector were also needed. These changes were not carried out in the first Dilma Rousseff government.

Reorganizing the country for this new development cycle initiated in the second term of the Dilma Rousseff government will need to be thought out, beyond the economy, and also social inclusion and administrative autonomy. Discussions in the Brazilian National Congress early this year already indicate that this will not be easy to achieve, especially given the unfavourable international situation.

On the other hand, however, provided there is Brazilian political coalition, and given the reduced influence of the banking and financial faction in decisions of Brazilian economic policy, this is an opportunity for the country to definitively break from the pattern of accumulation and subordinated international insertion, inherited nearly two decades ago, which has prevented sustained growth.

\footnotetext{
${ }^{1}$ Teixeira \& Pinto (2012) 938.
} 


\section{References}

Ankiw, N. G. (2001). Introdução à economia: princípios de micro e macroeconomia / tranalation Maria José Cyhlar Monteiro, 2 ed, Rio de Janeiro: Elsevier.

Baer, W. (1996). A Economia Brasileira. São Paulo: Nobel.

Bacha, E. L. (1995). 'Plano Real: Uma avaliação preliminar'. In: Revista do BNDES, vol. 3 jul./1995, p. 3-26.

Barbosa, N. \& J.A.O. Souza (2010a). 'A Inflexão do Governo Lula: Política Econômica, Crescimento e Distribuição de Renda', in: E. Sader e M. A. Garcia (orgs.). Brasil: entre o Passado e o Futuro. São Paulo: Fundação Perseu Abramo e Boitempo.

$<$ http://nodocuments.files.wordpress.com/2010/03/barbosa-nelson-souza-jose-antoniopereira-de-a-inflexao-do-governo-lula-politica-economica-crescimento-edistribuicao-de-renda.pdf.> Accessed on: January $23^{\text {rd }}, 2015$.

Barbosa, N. \& J.A.O. Souza (2010b). 'A Inflexão do Governo Lula: Política Econômica, Crescimento e Distribuição de Renda', in: E. Sader e M. A. Garcia (orgs.). A inflexão do governo lula: política econômica, crescimento e distribuição de renda.

Available at:

<http://nodocuments.files.wordpress.com/2010/03/barbosa-nelson-souza-jose-antoniopereira-de-a-inflexao-do-governo-lula-politica-economica-crescimento-edistribuicao-de-renda.pdf.> Accessed on: January $23^{\text {rd }}, 2015$.

Batista J.R. \& P. Nogueira (1987). International financial flows to Brazil since the late 1960s. World Bank Discussion Papers, 7. Washington, D.C.; World Bank, mar/1987, p. 34-51.

Cintra, M. \& L. Acioly (2012). 'O financiamento das contas externas brasileiras: 2003-2010’, in: Monteiro, A. et al. Brasil em desenvolvimento. Brasília: Ipea.

Doellinger, C. V. (1974). A política brasileira de comércio exterior e seus efeitos: 1967-73. Coleção Relatórios de Pesquisa, n 22, Rio de Janeiro: IPEA, pp. 23-47.

Fausto, B. (1997). A Revolução de 1930: historiografia e história.São Paulo: Companhia das Letras.

Grupo de Economia Fundap. (2014) Regime de política macroeconômica no governo Dilma. Available at: <http://www.fundap.sp.gov.br/wp-content/uploads/2014/03 /boletim_economia_7_conjuntura_economica.pdf.> Accessed on: January $23^{\text {rd }}$, 2015.

Ministério do desenvolvimento, indústria e comércio exterior (mdic). (2000 - 2011) Vários gráficos. Available at: http://<www.mdic.gov.br.> Accessed on: January $17^{\text {th }} 2015$.

Paulani, L. et. al. (1987). O heterodoxo e o pós-moderno: o cruzado em conflito. São Paulo: Paz e terra.

Pinho, D. B., Vasconcelos, M. A. S. de \& R. Toneto Júnior (orgs.) (2011). Manual de Economia. 6. ed São Paulo: Saraiva.

Tavares, M. da C. (1975). Da substituição de importações ao capitalismo financeiro: ensaios sobre economia brasileira. Rio de Janeiro: Zahar, 1975.

Teixeira, R. A. \&, Pinto, E. C. (2012). 'A economia política dos governos FHC, Lula e Dilma: dominância financeira, bloco no poder e desenvolvimento econômico' In: Economia e Sociedade, Vol. 21/dez, p. 909-941.

Vasconcelos, M. A. S. De, Gremaud, A. \& R. Toneto Júnior (1999) Economia Brasileira Contemporânea. 3. ed São Paulo: Atlas.

Villela, A. \& W. Baer (1980). O setor privado nacional: problemas e políticas para o seu fortalecimento. Coleção Relatório de Pesquisa 46. Rio de Janeiro: IPEA/INPES. 